\title{
Winter Pruning Affects Yield Components of 'Black Satin' Eastern Thornless Blackberry
}

\author{
Fumiomi Takeda ${ }^{1}$ \\ Appalachian Fruit Research Station, Agricultural Research Service, U.S. \\ Department of Agriculture, 45 Wiltshire Road, Kearneysville, WV 25430
}

Additional index words. Rubus, inflorescence, flowering, budbreak, fruit quality, floricane, primocane, crop productivity, total soluble solids, divided canopy trellis

\begin{abstract}
Nine-year-old 'Black Satin' blackberry (Rubus subgenus Rubus) plants were dormant pruned to three floricanes with three, six, nine, or twelve 12-node lateral branches $(\approx 108,216,324$, or 432 axillary buds per plant $)$ to determine the effect of lateral branch number on budbreak, fruit cluster number, fruit number per cluster, fruit weight, total soluble solids (TSS), and yield. Percent budbreak of primary and secondary axillary buds was reduced as the lateral branch number increased. Pruning did not affect fruit weight $(6.4 \mathrm{~g})$ or TSS $(9.5 \%)$. Yield per lateral branch was reduced as lateral branch number increased. A plant with three floricanes, each with 12 lateral branches, produced $21 \mathrm{~kg}$ of fruit. The results indicate that pruning lateral branches to a manageable length may be advantageous for eastern thornless blackberry trained on a divided canopy trellis.
\end{abstract}

Eastern thornless blackberries are highly productive and vigorous. Currently, cultivars such as 'Black Satin', 'Chester Thornless', 'Hull Thornless', and 'Triple Crown' are grown commercially on "I"-shaped hedgerows and on divided canopy trellis systems in the middle Atlantic coast, middle South, lower Midwest, and Pacific coast regions of the United States. Fruit can be hand-harvested for long-distance, wholesale fresh-market distribution (Charles and Anne Geyer, Westmoreland Berry Farm, Oak Grove, Va., personal communication). Both hand- and machine-harvested fruit have acceptable quality for the processor (Halat et al., 1997). The yield of blackberries is dependent, in part, on the number of nodes (buds) left on the floricanes after winter pruning. Reducing the floricane number and/or shortening the lateral branches by summer or winter pruning will generally decrease yields but often improve fruit quality in raspberries and blackberries (Crandall and Daubeny, 1990; Moore and Skirvin, 1990). Swartzet al. (1984), however, observed that node number was not always correlated with yield because not all primary and secondary buds produced a flowering shoot. Improved knowledge of the relationship between node number distribution and yield will help determine the best pruning method necessary for the blackberry trellis systems used.

Eastern thornless blackberries have a semierect growth habit and require trellis support. Canes are generally tied to form a narrow "V" or hedge-like canopy on an "I"- or "T"post trellis system. Divided canopy trellis systems have been reported to increase fruit production in raspberries (Crandall, 1980; Goulart

\footnotetext{
Received for publication 23 Mar. 2001. Accepted for publication 31 July 2001.

'Research Horticulturist. E-mail address: ftakeda@ afrs.ars.usda.gov
}

and Demchak, 1993; Nehrbas and Pritts, 1988; Oydvin, 1986) and in blackberries (Swartz et al., 1984). However, the effects of pruning and training thornless blackberries to a wide "V" canopy are not well known. As part of a research project to develop a machine-harvesting system for eastern thornless blackberries (Peterson et al., 1992; Takeda and Peterson, 1999), several eastern thornless blackberry cultivars were grown on a 2-m-wide and 2-mhigh "V" trellis with floricanes and primocanes trained and tied to separate sides of the "V" trellis. This trellis, like the Lincoln canopy trellis system (Dunn et al., 1976), the variations of the shift trellis (Stiles, 1995), and the rotatable cross-arm trellis (Takeda and Peterson, 1999), expands the canopy surface area and permits the floricanes and primocanes to be spatially separated on the trellis into two canopies. Primocanes were topped in summer $\approx 5 \mathrm{~cm}$ above the topmost wire of the trellis to promote lateral branch development. A high percentage of axillary buds on the lateral branches developed into flowering shoots the following spring. Understanding the effect of pruning on the fruitfulness of nodes is important in the harvesting of eastern thornless blackberries. Reducing the fruit maturity range is critical to developing an efficient machineharvesting system because concentrating the ripening period reduces the number of machine passes needed to harvest the crop.

This experiment was conducted to determine the effect of pruning severity on vegetative and reproductive growth characteristics of 'Black Satin' thornless blackberry trained to a "V" trellis.

\section{Materials and Methods}

Nine-year-old 'Black Satin' plants in a 0.5-ha block were established in 1983 at a 2.5 $\mathrm{m} \times 5.0 \mathrm{~m}$ spacing at the Appalachian Fruit
Research Station, Kearneysville, W.Va., on a Hagerstown silt loam soil (fine, mixed, Typic Hapludalf), and trained to a " $\mathrm{V}$ " trellis, in which the posts were set at $45^{\circ}$ from the horizontal to create a $90^{\circ}$ angle between the posts, for machine-harvesting research (Peterson et al., 1992). Plot maintenance and plant care followed the published bramble production guidelines for the region (Goulart et al., 1991). Plants received annual nutrient applications $\left(\mathrm{kg} \cdot \mathrm{ha}^{-1}\right)$ of N (45.5), P (19.6), and $\mathrm{K}$ (37.4) in April and supplemental irrigation as needed in June, July, and August. In 1992, primocanes were tied during the growing season to wires on the side of the "V" trellis void of floricanes and topped at a 2.8-m height to promote lateral branching. During the dormant season, the number of floricanes on each plant was reduced to three, and the lateral branches were pruned to retain three, six, nine, or twelve 12-node lateral branches on each of the three floricanes. In all cases, equal numbers of lateral branches were left in the top, middle, and bottom one-third of each floricane. During bloom in mid-May 1993, the number of fruit clusters (racemes) per lateral branch and their origin (primary or secondary axillary bud) were recorded. In June, fruit and flowers on all the racemes were counted. For yield and fruit quality determinations, all ripe fruit on selected lateral branches, one each at the top, middle, and bottom one-third portions of the floricanes, were handpicked, counted, and weighed at 2- to 3-d intervals over a 6-week period, starting on 8 July. Overripe fruit on other lateral branches were allowed to fall to the ground. To calculate the yield for the entire floricane at each harvest, the fruit weight for each section was multiplied with the number of lateral branches in the section and the weights from the three sections summed. Fruit were pooled for each plant and juice expressed through cheesecloth for total soluble solids (TSS) measurement with a digital refractometer (Atago Model PR-100, NSG Precision Cells, Inc., Farmingdale, N.Y.). A randomized complete-block design was used with four treatments and five replicates. A plot consisted of a single plant in a row with one plant on either side. These adjacent plants were pruned to three floricanes with six to nine lateral branches. Data were subjected to regression analysis to determine whether any linear and quadratic effects occurred due to the number of lateral branches on several yield components, using SAS REG PROC (SAS Institute, Cary, N.C.).

\section{Results and Discussion}

The development of reproductive components in response to pruning level $(\approx 108,216$, 324 , or 432 axillary buds per plant) was characterized (Fig. 1). In general, there was little or no evidence of any quadratic effects due to the number of lateral canes. Pruning to 12 lateral branches decreased primary and secondary axillary bud emergence compared to three lateral branches (Fig. $1 \mathrm{~B}$ and C). As a result, the number of racemes per lateral branch decreased as lateral branch number increased (Fig. 1D). 

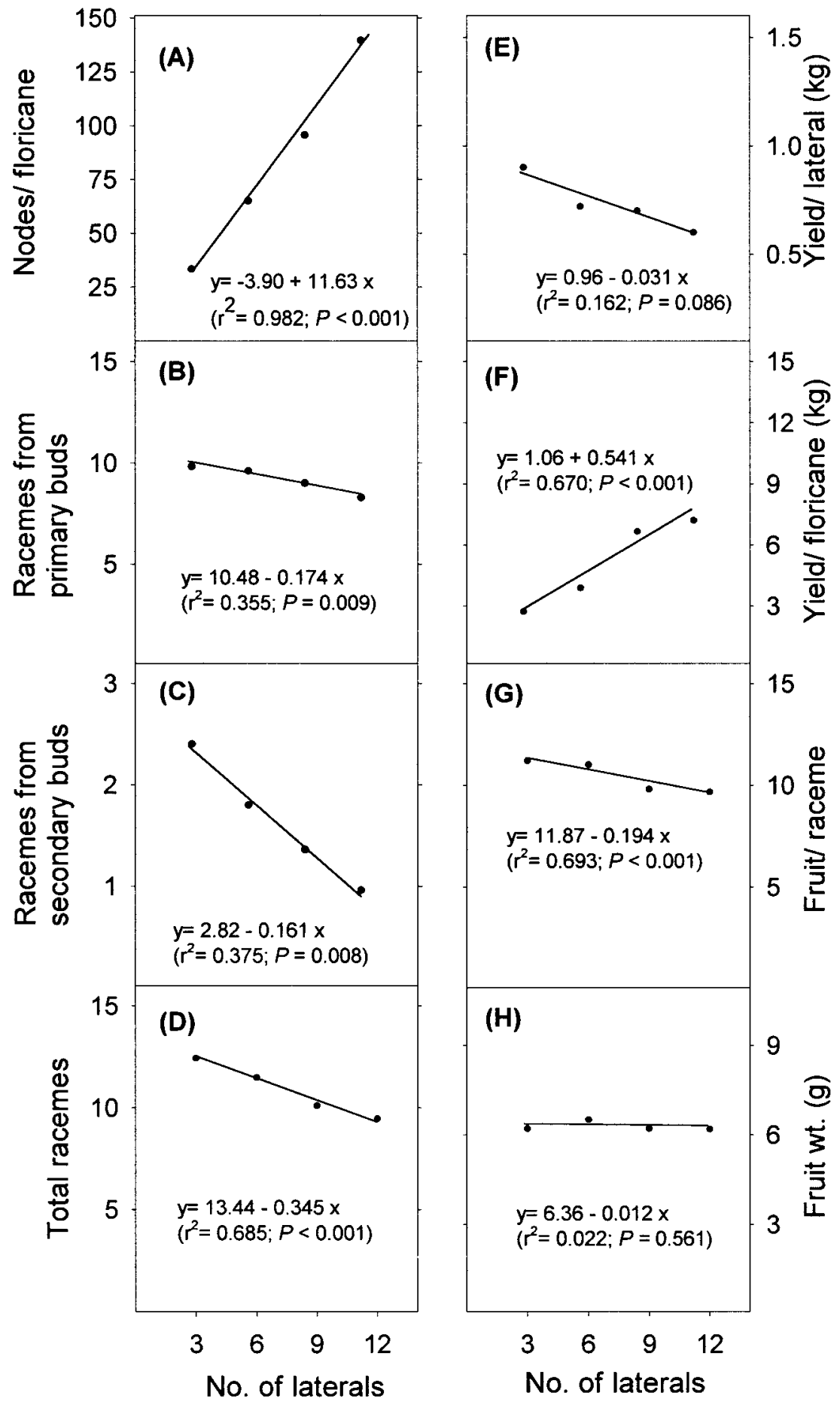

tion $(\approx 9.4 \% \pm 0.7 \%)$ or fruit weight (Fig. $1 \mathrm{H})$.

In all treatments, ripe fruit were harvested over a 6- to 7-week period (data not presented). Most fruit on lateral branches at the top one-third of the floricane ripened in the initial 2 weeks. Thereafter, yield declined during the following 5 weeks. Fruit harvests in the middle and bottom one-third sections peaked in the third week and then gradually declined. For plants with only three or six lateral branches per floricane, there was a small increase in yield late in the season due primarily to the delayed maturation of fruit on the racemes originating from secondary axillary buds. The difference in growth and developmental processes, such as floral bud differentiation and budbreak, between the secondary and primary axillary buds at a node can be as much as 2 or 3 weeks (Takeda, 1987; Takeda and Wisniewski, 1989).

The results of this experiment suggest that pruning can affect the fruitfulness of nodes, and this may influence the maturity range. Concentrated ripening period reduces the number of machine passes needed to harvest the crop and aids in improving machine-harvesting efficiency. Previously, Takeda (1987) reported that extended bloom in large racemes was a major factor accounting for a wide fruit maturity range in 'Black Satin' and 'Hull Thornless' blackberries. Perhaps concentrated ripening could be achieved if fruiting laterals were less vigorous, i.e., fewer flowers per raceme. The results of this study indicate that raceme size (number of flowers or fruit per raceme) can be reduced if plants are lightly pruned. Severe pruning invigorates the fruiting lateral to produce larger racemes and increases the percentage of total yield derived from secondary axillary buds. An increase in budbreak and larger racemes would increase maturity range (Takeda, 1987).

Floral bud initiation in the primary axillary buds of 'Black Satin' blackberry starts in the fall, but much of the bud differentiation occurs in early spring during the 2-month period prior to bloom (Takeda and Wisniewski, 1989). This suggests that the eastern thornless blackberries must adjust to pruning severity by increasing the size of raceme and degree of floral bud differentiation of secondary axillary buds subsequent to winter pruning. Although not part of this study, 'Black Satin' blackberry plants trained on divided canopy trellis systems and pruned annually to $\approx 400$ nodes have consistently yielded $20 \mathrm{~kg}$ of fruit each year from 1988 to 1994 . For several years now, 'Chester Thornless' blackberry plants trained on a rotatable cross-arm trellis system (Takeda and Peterson, 1999) have produced as many as six primocanes and yields of 15-19 kg per plant without reducing the growth of new primocanes (number and length) (data unpublished). The current study demonstrated that light pruning (e.g., leaving 12 lateral branches/ floricane) did not reduce yield, but decreased the raceme size and fruiting laterals that developed from secondary buds. Cane training and pruning techniques affect the range of fruit maturity and harvest duration. Sufficient growth and development of lateral branches 
from the main primocanes is needed to attain a high plant productivity and improve efficiency for mechanical harvesting of "V"-trellised thornless blackberry.

\section{Literature Cited}

Crandall, P.C. 1980. Twenty years of red raspberry research in southwestern Washington State. Acta Hort. 112:53-58.

Crandall, P.C. and H.A. Daubeny. 1990. Raspberry management, p. 157-213. In: G.J. Galletta and D.G. Himelrick (eds.). Small fruit crop management. Prentice Hall, Englewood Cliff, N.J.

Dunn, J.S., M. Stolp, and G.G. Lindsay. 1976 Mechanical raspberry harvesting and the Lincoln canopy system. Amer. Soc. Agr. Eng. Paper 76-1543, St. Joseph, Mich

Goulart, B.L., M. Brittingham, J. Harper, P Heinemann, W. Hock, E. Rajotte, J. Rytter, and J. Travis. 1991. Small fruit production and pest management guide, 1991-92.Pennsylvania State Univ., University Park.

Goulart, B.L. and K. Demchak. 1993. Physiological responses of "T", "V" and hedgerow trained red and black raspberries (Rubus ideaus L. and $R$. occidentalis L.). Acta Hort. 352:159-167.

Halat, M.S., C.A. Reitmeier, F. Takeda, and D.L. Peterson. 1997. Sensory evaluation of jams made from three eastern thornless and Marion blackberries. J. Food Quality 20:177-188.

Moore, J.N. and R.M. Skirvin. 1990. Blackberry management, p. 214-244. In: G.J. Galletta and D.G. Himelrick (eds.). Small fruit crop management. Prentice Hall, Englewood Cliff, N.J.

Nehrbas, S.R. and M.P. Pritts. 1988. Effect of training system on performance of hand-harvested summer-bearing raspberries. HortScience 23:126-127.

Oydvin, J. 1986. The Gjerde method for training raspberries. Effects of increasing cane number and cane height. Acta Hort. 183:173-174.

Peterson, D.L., F. Takeda, and T. Kornecki. 1992.
Harvester for "T", "V", and "Y" trellised eastern thornless blackberries. Appl. Eng. Agr. 8:9-12. Stiles, H.D. 1995. Shift-trellises for better management of brambles (Rubus cvs.). Va. Agr. Expt. Sta. Bul. Ser. 95-2, Blacksburg.

Swartz, H.J., S.E. Gray, L.W. Douglas, E. Durner, C.S. Walsh, and G.J. Galletta. 1984. The effect of divided canopy trellis design on thornless blackberry. HortScience 19:533-535.

Takeda, F. 1987. Some factors associated with fruit maturity range in cultivars of the semi-erect, tetraploid thornless blackberry. HortScience 22:405-408.

Takeda, F. and D.L. Peterson. 1999. Considerations for machine harvesting fresh-market eastern thornless blackberries: Trellis design, cane training systems, and mechanical harvester developments. HortTechnology 9:16-21.

Takeda, F. and M. Wisniewski. 1989. Organogenesis and patterns of floral bud development in two eastern thornless blackberry cultivars. J. Amer. Soc. Hort. Sci. 114:528-531. 